\title{
EFFICIENCY OF PHYTOGENIC FEED ADDITIVES IN IMPROVING BROILER PERFORMANCE, INTESTINAL BACTERIA AND ILEAL HISTOMORPHOLOGY.
}

\author{
Nagla K. Soliman \\ Department of Poultry Production, Faculty of Agriculture, Ain Shams University, Cairo 11241, Egypt.
}

(Received 15/5/2019, accepted 4/7/2019)

\section{SUMMARY}

$\mathrm{P}$

hotogenic feed additives (PFA) have been suggested to promote broiler performance as alternative for antibiotics, which have been banned from the feed. The current study aimed to evaluate the effect of dietary PFA (Biostrong ${ }^{\circledR}$ 510) on performance of broiler chicks, ileal content of bacteria, intestinal histomorphology and blood characteristics under the environmental conditions of Saudi Arabia Kingdom. Four-hundred-day-old Ross broiler chicks were allocated to four treatment groups with five replicates of 20 birds each. For 35 days experimental period, the chicks were fed on four different experimental diets: 1) positive control diet containing $21.24 \%$ crude protein and $2850 \mathrm{Kcal} \mathrm{ME;} \mathrm{2)} \mathrm{positive} \mathrm{control} \mathrm{with} 150 \mathrm{~g} / \mathrm{t}$ Biostrong® 510 added to the diet; 3) negative control diet containing $20.49 \%$ crude protein and $2801 \mathrm{Kcal} \mathrm{ME}$; 4) negative control with $150 \mathrm{~g} / \mathrm{t}$ Biostrong 510®added to the diet. Dietary addition of Biostrong ${ }^{\circledR} 510$ significantly increased body weight gain and feed conversion compared to birds fed the two control diets at the second stage of growth (3-5 wk.). Photogenic feed additive supplementation significantly reduced ileal content of E. coli and increased Lactobacillus bacteria. Plasma total protein, albumin, globulin, cholesterol, or triglycerides were not affected by adding Biostrong ${ }^{\circledR} 510$ into the diet. There is no significant effect on relative weight of the liver, spleen, heart or bursa of Fabricius between the different treatments. The results revealed a significant increase in villi length associated with a reduction in crypt depth due to inclusion of PFA into broiler diets. The small intestine thickness significantly reduced due to inclusion of PFA into the diet. From the current study, we can conclude that PFA supplementation has a positive effect on increasing the number of beneficial bacteria and villi length which improves nutrient digestibility and broiler performance.Keywords: phytogenic feed additive, broiler performance, blood constitutes.

\section{INTRODUCTION}

The use of antibiotics as a growth promoter for poultry diets have been banned several years ago (Cardoso et al., 2012). Therefore, to keep the high production performance of poultry and livestock, most nutrition researchers have been aimed to find suitable alternatives for antibiotics, which increase nutrient digestibility and utilization via improving intestinal microflora and villi health.

The phytogenic term indicates a blend of plants, herbs, spices, or their extracts of essential oils, which have several beneficial properties as antimicrobial and antioxidant agents (Kang et al., 2010). A wide variety of plants have been established as phytogenic feed additives (PFA) in poultry rations such as garlic, anise, oregano, thyme, rosemary, coriander, and cinnamon, as well as their bioactive components like allicin, carvacrol, thymol, capsaicin, and piperine (Murugesan et al., 2015). These phytogenic compounds have a beneficial effect in enhancing efficiency of feed utilization, intestinal microflora pattern and stimulation of immune response of poultry (Saleh et al., 2018). Several studies indicate that phytogenic compounds can be a natural alternative for antibiotics in poultry diets (Murugesan et al., 2015; Wati et al., 2015). The antimicrobial properties of PFA have been reported later by Cho et al. (2014). They reported that inclusion of PFA containing essential oils of thyme and star anise into broiler diets reduced the intestinal content of Clostridium Perfringens and E. Coli bacteria. Mountzouris et al. (2011) observed an increase of caecal Lactobacillus, Bifidobacterium, and a significant decrease in caecal coliform bacteria by adding a blend of essential oils from oregano, anise, and citrus into broiler diets. However, Ahsan et al. (2018) did not find any effect on caecal microbe populations due to supplementing broiler chicks with commercial PFA. The role of PFA in enhancing intestinal morphology and nutrient utilization was studied by Ahsan et al. (2018), Mohiti-Asli and Ghanaatparast-Rashti (2017) who 


\section{Soliman}

observed an increase in villus height, villus width and muscularis thickness in broilers fed different spices and oils. However, this improvement did not reflect on chick performance which did not response for PFA supplementation. Similar results were concluded by Murugesan et al. (2015). They noted a significantly increased villus height and nutrient digestibility of broiler chicks fed diets with commercial PFA, which enhance feed conversion and body weight gain. As well, numerous studies observed an improvement in nutrient digestibility, feed efficiency and body weight gain due to inclusion of different types of PFA into broiler diets (Cho et al., 2014; Mountzouris et al., 2011; Li et al., 2015; Paraskeuas et al., 2017).

A commercial PFA blend (Biostrong ${ }^{\circledR}$ 510, Delacon Biotechnik GmbH, Steyregg, Austria) has been studied in the past already under different environmental conditions in the world. Leopold et al. (2011), Amad et al. (2013) and El-Faham et al. (2014) showed that inclusion of Biostrong ${ }^{\circledR} 510$ into broiler diets improved feed conversion ratio, gut health, and nutrient digestibility. On the other hand, Scheuermann et al. (2009) and Beiki et al. (2013) did not find any differences in feed conversion ratio or body weight gain by adding Biostrong ${ }^{\circledR} 510$ into broiler diets.

Nowadays, the information concerning the efficacy of PFA products in improving performance of broiler chicks under hot, high humidity, like the typical environmental condition of Arabic Gulf countries is still lacking. Hence, the current study aimed to evaluate the effect of dietary PFA on performance characteristics of broiler chicks, ileal content of bacteria, intestinal histomorphology and blood characteristics under the environmental conditions of Saudi Arabia Kingdom.

\section{MATERIALS AND METHODS}

\section{Experimental Procedure:}

The current study was conducted at an experimental poultry farm, animal production department, at the College of Agriculture and food science, King Faisal University, Saudi Arabia Kingdom. For 35 days, 400-day-old Ross broiler chicks were allocated randomly into 4 treatment groups with five replicates of 20 birds each. The four groups of chicks were fed on four different experimental diets as follows: 1) positive control diet containing $21.24 \%$ crude protein and $2850 \mathrm{Kcal} \mathrm{ME;} \mathrm{2)} \mathrm{positive} \mathrm{control} \mathrm{with} 150 \mathrm{~g} / \mathrm{t}$ Biostrong ${ }^{\circledR} 510$ added to the diet; 3 ) negative control diet containing $20.49 \%$ crude protein and 2801 Kcal ME;4) negative control with $150 \mathrm{~g} / \mathrm{t}$ Biostrong ${ }^{\circledR} 510$ added to the diet. The diets were formulated to meet the requirements of broilers according to NRC (1994) and are shown in Table (1). Biostrong ${ }^{\circledR} 510$ contains essential oils of thyme and anise, mixed with different herbs and spices.

Water and feed were provided $a d$ lib. The chicks were placed in floor pens with wood-shavings litter. Electrical heaters were used for warming. Fan and air conditions were used for keeping a suitable temperature. Artificial lighting was provided constantly. Body weight was recorded weekly for each chick and the average weight was calculated for each replicate and treatment group. Feed consumption values were recorded weekly in gram, and feed conversion ratio was calculated as gram feed/gram gain.

\section{Slaughtered traits and sample collection:}

At the end of the experimental period, 10 chicks per treatment group were slaughtered, allowed to bleed for a blood sample. Internal organs were separated. The weight of the liver, spleen and bursa of Fabricus were recorded. Ileal content samples were collected in clean sterile glass bottles. Small intestine thickness was determined as the procedures described by Stutz et al. (1983) and calculated as: small intestine weight $(\mathrm{g}) /$ small intestine length $(\mathrm{cm})$.

\section{Blood analysis:}

Blood samples were collected in heparinized tube and centrifuged at $3000 \mathrm{rpm}$ for 15 minutes. Plasma was separated and stored at $-20{ }^{\circ} \mathrm{C}$ until further analysis. Plasma total protein was determined according to the Biuret method (Henery, 1964) and albumin was determined according to Doumas et al. (1971). Plasma globulin was calculated by subtracting albumin from total protein. Plasma total lipid was determined according to Knight et al. (1972) and total cholesterol according to Watson (1960). 
Egyptian J. Nutrition and Feeds (2018)

Table (1): Composition and calculated analysis of experimental control diets.

\begin{tabular}{lcc}
\hline Ingredient & Control (+) & Control (-) \\
\hline Yellow corn & 60.0 & 59.0 \\
Soybean meal $(48 \%)$ & 31.5 & 29.0 \\
Wheat bran & 5.5 & 9.0 \\
Dicalcium phosphate & 1.0 & 1.0 \\
Limestone & 1.3 & 1.3 \\
Salt & 0.25 & 0.25 \\
Vit. \& min. premix* & 0.33 & 0.33 \\
DL-Methionine & 0.12 & 0.12 \\
Total & 100 & 100 \\
Calculated composition & & \\
Crude protein (\%) & 21.24 & 20.49 \\
ME (Kcal/kg) & 2850 & 2801 \\
Calcium (\%) & 0.82 & 0.82 \\
Av. phosphorus (\%) & 0.315 & 0.315 \\
Meth + Cyst (\%) & 0.68 & 0.67 \\
Lysine (\%) & 1.12 & 1.07 \\
*Composition of vitamin and mineral premix. Each 2.5 kg of vitamin and mineral mixture contains: 12000000 IU \\
vitamin A; 200000 IU D3; 10gvitamin E; 1gvitamin K; 1 g vitaminB1; 5g vitaminB2; 1500mg vitaminB6; 10mg \\
vitaminB12;10g Pantothenic acid; 20g Nicotinic acid; $1 \mathrm{~g}$ Folic acid; 50mg Biotin; 500g choline chloride; $4 \mathrm{~g}$ copper; \\
300mg iodine; 30g iron; 60g manganese; 50g zinc; 100mg selenium
\end{tabular}

\section{Intestinal bacteria:}

For microbiological examination, one gram of ileal content was transferred into test tubes containing 9 $\mathrm{ml}$ of 0.1 sterile peptone. The samples were mixed well; a tenfold dilution was prepared and titrated on the following media:

Total aerobic bacteria were cultured on nutrient agar medium composed of $2.5 \mathrm{~g}$ yeast extract, $5 \mathrm{~g}$ trypton, $1 \mathrm{~g}$ glucose, $15 \mathrm{~g}$ agar and distilled water up to one liter.

Lactobacilli bacteria were cultured on M.R.S. agar medium which is composed of $10 \mathrm{~g}$ casein peptone, $10 \mathrm{~g}$ meat extract, $5 \mathrm{~g}$ yeast extract, $20 \mathrm{~g}$ glucose, $1 \mathrm{~g}$ tween 80,2 $\mathrm{g} \mathrm{K} \mathrm{K}_{2}$ mpo $4,5 \mathrm{~g}$ sodium acetate, $2 \mathrm{~g}$ diammonium citrate, $0.2 \mathrm{~g} \mathrm{MnSO}_{4}$ and distilled water up to 1 liter.

E. coli bacteria were cultured on MacChonkey agar medium that is composed of $17 \mathrm{~g}$ pancreatic digest of gelatin, $1.5 \mathrm{~g}$ pancreatic digest of casein, $1.5 \mathrm{~g}$ peptic of animal tissue, $10 \mathrm{~g}$ lactose, $1.5 \mathrm{~g}$ bile salts, $5 \mathrm{~g}$ sodium chloride, $0.03 \mathrm{~g}$ neutral red, $0.001 \mathrm{~g}$ crystal violet, $3.5 \mathrm{~g}$ agar and distilled water up to 1 liter.

Enterobacteria were cultured on MacChonkey agar No.2 medium that is composed of (peptone $20 \mathrm{~g}$., lactose $10 \mathrm{~g}$., bile salt $5 \mathrm{~g}$., sodium chloride $5.0 \mathrm{~g}$., neutral red $0.075 \mathrm{~g}$ and agar, $12 \mathrm{~g}$ per liter). Salmonella bacteria were cultured on S.S. agar. Bacterial count was determined by microscopic examination of the cultured media.

\section{Histomorpholgical examination:}

A small portion $(2.5 \mathrm{~cm})$ of the slaughtered birds' ileum was dissected and placed in $10 \%$ buffered neutral formalin for fixation. A microtome was used to make $5 \mu$ sections that were mounted on glass slides and stained with hematoxylin and eosin. Villi length was measured from the apical to the basal region which corresponded to the superior portion of the crypts of Lieberkühn by using light microscope fitted with a digital camera and images were analyzed using image analysis software.

\section{Statistical analysis:}

Statistical analysis was carried out using the statistical program SAS (1988). Duncan's multiple range test (1955) was applied for significant differences among means of traits. The following model was used:

$$
\mathrm{Yij}=\mu+\mathrm{Ti}+\mathrm{eij} \text {. }
$$

Where Yij = observation, $\mu=$ overall means, $\mathrm{Ti}=$ effect of treatment and eij $=$ experimental error. 


\section{RESULTS AND DISCUSSION}

Performance aspects of broiler chicks are summarized in Table (2). Body weight gain did not response for Biostrong ${ }^{\circledR} 510$ supplementation at the first stage of growth $(0-3 \mathrm{wk})$, however there was a significant $(\mathrm{P} \leq 0.05)$ increase in body weight gain of birds fed negative control diet with Biostrong ${ }^{\circledR} 510$ at the second stage of growth (3-5 wk) and for the overall experimental period (0-5 wk). The interaction between PFA and age has been demonstrated earlier by Mountzouris et al. (2011) and Cho et al. (2014), who observed an improvement in broiler performance due to feeding dietary PFA after 21 days of age and concluded that the beneficial effect of PFA is age dependent. On the other hand, Amad et al. (2013) did not observe any significant effect on body weight of broilers feeding dietary Biostrong ${ }^{\circledR}$ 510. Mountzouris et al. (2011) reported that the gain to feed ratio improved with adding PFA during the finisher period. The role of Biostrong ${ }^{\circledR} 510$ in enhancing broiler performance may be related to its effect in improving intestinal bacteria balance and increasing nutrient digestibility (Cho et al., 2014).

Table (2) Effect Biostrong®510 on Performance of Broiler Chicks

\begin{tabular}{|c|c|c|c|c|}
\hline Item & Control (+) & $\begin{array}{l}\text { Control (+) with } \\
\text { Biostrong®510 }\end{array}$ & Control (-) & $\begin{array}{l}\text { Control (-) with } \\
\text { Biostrong } ® 510\end{array}$ \\
\hline \multicolumn{5}{|c|}{ Body weight gain $(\mathrm{g})$} \\
\hline 0-3 wk. age & $\begin{array}{l}581.7 \\
\pm 16.4\end{array}$ & $\begin{array}{l}595.6 \\
\pm 20.4\end{array}$ & $\begin{array}{r}626.9 \\
\pm 15.1\end{array}$ & $\begin{array}{r}627.0 \\
\pm 12.6\end{array}$ \\
\hline 3-5 wk. age & $\begin{array}{l}856.4^{\mathrm{b}} \\
\pm 37.7\end{array}$ & $\begin{array}{l}889.9^{\mathrm{ab}} \\
\pm 11.6\end{array}$ & $\begin{array}{l}882.8^{\mathrm{ab}} \\
\pm 23.0\end{array}$ & $\begin{array}{l}960.3^{\mathrm{a}} \\
\pm 31.1\end{array}$ \\
\hline $0-5$ wk. age & $\begin{array}{l}1438.1^{\mathrm{b}} \\
\pm 49.6\end{array}$ & $\begin{array}{c}1485.5^{\mathrm{ab}} \\
\pm 30.9\end{array}$ & $\begin{array}{c}1509.7^{\mathrm{ab}} \\
\pm 17.2\end{array}$ & $\begin{array}{l}1587.5^{\mathrm{a}} \\
\pm 43.4\end{array}$ \\
\hline \multicolumn{5}{|c|}{ Feed intake $(g)$} \\
\hline 0-3 wk. age & $\begin{array}{l}945.9^{\mathrm{a}} \\
\pm 31.3\end{array}$ & $\begin{array}{l}951.9^{\mathrm{b}} \\
\pm 30.0\end{array}$ & $\begin{array}{c}1009.8^{\mathrm{ab}} \\
\pm 14.7\end{array}$ & $\begin{array}{l}1042.7^{\mathrm{a}} \\
\pm 15.5\end{array}$ \\
\hline 3-5 wk. age & $\begin{array}{c}1616.5^{\mathrm{ab}} \\
\pm 53.9\end{array}$ & $\begin{array}{l}1532.5^{b} \\
\pm 25.2\end{array}$ & $\begin{array}{c}1659.5^{\mathrm{ab}} \\
\pm 38.4\end{array}$ & $\begin{array}{l}1756.3^{\mathrm{a}} \\
\pm 67.4\end{array}$ \\
\hline $0-5$ wk. age & $\begin{array}{c}2562.5^{\mathrm{b}} \\
\pm 72.4\end{array}$ & $\begin{array}{c}2484.4^{\mathrm{b}} \\
\pm 54.8\end{array}$ & $\begin{array}{c}2669.3^{\mathrm{ab}} \\
\pm 43.6\end{array}$ & $\begin{array}{c}2799.1^{\mathrm{a}} \\
\pm 82.8\end{array}$ \\
\hline \multicolumn{5}{|c|}{ Feed efficiency (g feed/g gain) } \\
\hline 0-3 wk. age & $\begin{array}{c}1.62 \\
\pm 0.02\end{array}$ & $\begin{array}{c}1.60 \\
\pm 0.036\end{array}$ & $\begin{array}{c}1.61 \\
\pm 0.025\end{array}$ & $\begin{array}{c}1.67 \\
\pm 0.009\end{array}$ \\
\hline 3-5 wk. age & $\begin{array}{c}1.89^{\mathrm{a}} \\
\pm 0.04\end{array}$ & $\begin{array}{c}1.72^{\mathrm{b}} \\
\pm 0.022\end{array}$ & $\begin{array}{c}1.88^{\mathrm{a}} \\
\pm 0.033\end{array}$ & $\begin{array}{c}1.83^{\mathrm{a}} \\
\pm 0.027\end{array}$ \\
\hline $0-5$ wk. age & $\begin{array}{c}1.79^{\mathrm{a}} \\
\pm 0.032\end{array}$ & $\begin{array}{c}1.68^{\mathrm{b}} \\
\pm 0.023\end{array}$ & $\begin{array}{c}1.77^{\mathrm{a}} \\
\pm 0.024\end{array}$ & $\begin{array}{c}1.76^{\mathrm{a}} \pm \\
0.018\end{array}$ \\
\hline
\end{tabular}

Means \pm (Standard error)

Values within a row with different superscripts are significantly different $(P \leq 0.05)$

Ileal content of bacteria strains and bacterial total count are shown in Table (3). Adding Biostrong ${ }^{\circledR} 510$ into the broiler diet resulted in a significant $(\mathrm{P} \leq 0.05)$ reduction in pathogenic E. coli bacteria and a numerical reduction in count of Enterobacteria. In contrast, Lactobacillus bacterial strain and total count of ileal bacteria increased due to Biostrong ${ }^{\circledR} 510$ supplementation. The increase was significant $(\mathrm{P} \leq 0.05)$ for Lactobacillus only. The current results are in a good agreement with the previous studies which indicate the reduction of intestinal content of E. coli and Enterobacteria associated with the increase in the count of Lactobacillus bacteria due to inclusion of different types of PFA into broiler diets (Ahsan et al., 2018; Saracila et al., 2018; Mohiti-Asli and Ghanaatparast-Rashti, 2017; Murugesan et al., 2015). Several reports related the antimicrobial activity of PFA to its content of herbal essential oils which showed in vitro antimicrobial activity (Hafeez et al., 2016; Ahsan et al., 2018). The essential oil of thyme (one of the Biostrong ${ }^{\circledR} 510$ components) disrupt the lipid structure of the bacterial cell membrane, damage its permeability for specific ions and its metabolic activity, which results in death of the bacterial cells (Ultee et al., 2002; Mohiti-Asli and Ghanaatparast-Rashti, 2017). Supplementation of PFA may ensure proper conditions for inducing the proliferation of beneficial Lactobacilli bacteria (Saracila et al., 2018) which selectively exclude the E. coli and pathogenic bacteria from adhering to the intestine due to their fast proliferation and acidification properties in the small intestine (Murugesan et al., 2015). 
Egyptian J. Nutrition and Feeds (2018)

Table (3) Effect of Biostrong® 510 on ileal content of bacteria

\begin{tabular}{lcccc}
\hline Bacterial Strain & Control (+) & $\begin{array}{c}\text { Control (+) with } \\
\text { Biostrong® 510 }\end{array}$ & Control (-) & $\begin{array}{c}\text { Control (-) with } \\
\text { Biostrong® } 510\end{array}$ \\
\hline Lactobacilli sp. & $0.68 \times 10^{6} \mathrm{~b}$ & $3.7 \times 10^{6} \mathrm{~b}$ & $1.9 \times 10^{6} \mathrm{~b}$ & $33 \times 10^{6} \mathrm{a}$ \\
(cfu/g) & \pm 4.62 & \pm 5.55 & \pm 2.60 & \pm 4.36 \\
E. coli & $3.4 \times 10^{6} \mathrm{a}$ & $0.8 \times 10^{6} \mathrm{~b}$ & $1.3 \times 10^{6} \mathrm{ab}$ & $0.078 \times 10^{6} \mathrm{c}$ \\
(cfu/g) & \pm 13.91 & \pm 9.24 & \pm 17.85 & \pm 9.39 \\
Enterobacteria & $6.4 \times 10^{5}$ & $9.6 \times 10^{5}$ & $10.1 \times 10^{5}$ & $0.19 \times 10^{6}$ \\
(cfu/g) & \pm 31.93 & \pm 39.44 & \pm 51.91 & \pm 10.54 \\
Bacterial total count & $8.8 \times 10^{6}$ & $6.1 \times 10^{6}$ & $5.3 \times 10^{6}$ & $13.5 \times 10^{6}$ \\
(cfu/g) & \pm 12.50 & \pm 27.47 & \pm 23.95 & \pm 73.99 \\
\hline
\end{tabular}

Means \pm (Standard error)

Values within a row with different superscripts are significantly different $(P \leq 0.05)$.

Plasma content of protein, lipids and their derivatives are shown in Table (4). The values of plasma total protein, albumin or globulin within different treatments were similar and lacked significance. As well, there is no significant effect of Biostrong ${ }^{\circledR} 510$ on plasma content of cholesterol or triglycerides. The results indicate that Biostrong ${ }^{\circledR} 510$ has no effect on protein or lipid metabolism of broiler chicks. The present results are in harmony with those of Paraskeuas et al. (2017), who didn't observe any effect on plasma cholesterol, triglycerides or total protein due to inclusion of Biostrong ${ }^{\circledR} 510$ into broiler diets. In contrary, Amad et al. (2013) reported an increase in serum cholesterol, total protein, and albumin by adding Biostrong ${ }^{\circledR} 510$ into broiler diets. There is no explanation for this disagreement which may be related to the differences in experimental conditions and determination means.

Table (4) Effect of Biostrong® 510 on blood constituents

\begin{tabular}{lcccc}
\hline Blood & Control $(+)$ & $\begin{array}{c}\text { Control (+) with } \\
\text { Biostrong® 510 }\end{array}$ & Control (-) & $\begin{array}{c}\text { Control (-) with } \\
\text { Biostrong® 510 }\end{array}$ \\
\hline Total Protein & 2.85 & 2.89 & 2.92 & 2.93 \\
$(\mathrm{mg} / \mathrm{dl})$ & \pm 0.097 & \pm 0.051 & \pm 0.068 & \pm 0.086 \\
Albumin & 1.69 & 1.78 & 1.67 & 1.68 \\
$(\mathrm{mg} / \mathrm{dl})$ & \pm 0.029 & \pm 0.039 & \pm 0.028 & \pm 0.037 \\
Globulin & 1.148 & 1.108 & 1.260 & 1.240 \\
$(\mathrm{mg} / \mathrm{dl})$ & \pm 0.102 & \pm 0.72 & \pm 0.066 & \pm 0.095 \\
Cholesterol & 128.6 & 117.8 & 119.8 & 113.8 \\
$(\mathrm{mg} / \mathrm{dl})$ & \pm 5.58 & \pm 5.05 & \pm 3.80 & \pm 9.15 \\
Triglyceride & 59.4 & 40.4 & 61.4 & 66.3 \\
$(\mathrm{mg} / \mathrm{dl})$ & \pm 3.44 & \pm 2.73 & \pm 1.82 & \pm 1.73 \\
\hline
\end{tabular}

Means \pm (Standard error)

Values within a row with different superscripts are significantly different $(P \leq 0.05)$.

The weight of internal organs as percentage to dressing carcass weight was cited in Table (5). There is no significant $(\mathrm{P} \leq 0.05)$ effect on relative weight of the liver, spleen, heart, or bursa of Fabricius due to supplementation of Biostrong ${ }^{\circledR} 510$ to broiler diet. The previous results of Li et al. (2015), Saracila et al. (2018) and Saleh et al. (2018) did not find any significant effect on internal organ weight as a result of adding different types of PFA into broiler diets. On the other hand, Amad et al. (2011) noted a significant reduction in liver weight due to feeding different levels of Biostrong ${ }^{\circledR} 510$ to broiler chicks.

Ileal histomorphology results (Table 6 \& Fig 1) revealed a significant $(P \leq 0.05)$ increase in villi length associated with a reduction in crypt depth due to inclusion of PFA into broiler diets. Accordingly, the ratio of villi length to crypt depth was significantly higher due to feeding diets supplemented with PFA. As well, there were significant $(\mathrm{P} \leq 0.05)$ reductions in small intestine thickness for the birds fed Biostrong ${ }^{\circledR} 510$ supplemented diets. The current results are in a good agreement with those of Ahsan et al. (2018) and Mohiti-Asli and Ghanaatparast-Rashti (2017), who observed an increase in villi height and villi height to crypt depth ratio inherent with reductions in crypt depth and muscular thickness by including PFA into broiler diets. The morphological changes in the small intestine may illustrate the beneficial action of Biostrong ${ }^{\circledR} 510$ in enhancing the performance of broiler chicks. The reason is that the higher villi increase the surface area for nutrients absorption, ultimately increasing the efficiency of feed 


\section{Soliman}

utilization and body weight gain (Murugesan et al., 2015). The intestinal crypts are a reservoir for epithelial cells renewal which consumes more nutrients for cell build up and turnover, so low value of crypt depth in Biostrong ${ }^{\circledR} 510$ feeding groups may allow more nutrients for body growth (Ahsan et al., 2018). As well, the reduction in small intestine thickness usually associates with a low count of harmful bacteria which induce a chronic intestinal wall inflammation (Krink and Jamroz, 1996). Therefore, thinner wall of Biostrong ${ }^{\circledR} 510$ feeding groups indicate a low count of harmful bacteria and better nutrient absorption (Ahsan et al., 2018).

Table (5) Effect of Biostrong® 510 on relative weight of internal organs

\begin{tabular}{lcccc}
\hline Organ & Control (+) & Control (+) with & Control (-) & $\begin{array}{c}\text { Control (-) with } \\
\text { Biostrong® 510 }\end{array}$ \\
\hline \multirow{2}{*}{ Dressing wt. (g) } & 1350.5 & 1274.0 & 1334.3 & 1358.2 \\
\% Liver & \pm 72.2 & \pm 42.5 & \pm 50.7 & \pm 41.6 \\
& 3.24 & 3.25 & 3.19 & 3.10 \\
\% Spleen & \pm 0.185 & \pm 0.089 & \pm 0.121 & \pm 0.066 \\
& 0.131 & 0.133 & 0.149 & 0.128 \\
\% Hart & \pm 0.010 & \pm 0.011 & \pm 0.009 & \pm 0.007 \\
& 0.758 & 0.757 & 0.722 & 0.721 \\
Bursa wt. (g) & \pm 0.029 & \pm 0.031 & \pm 0.044 & \pm 0.019 \\
& 3.09 & 2.97 & 3.71 & 3.29 \\
\hline
\end{tabular}

Means $\pm($ Standard error)

Values within a row with different superscripts are significantly different $(P \leq 0.05)$

Table (6) Effect of PFA on Small Intestine Thickness and Ileal Histomorphology

\begin{tabular}{lcccc}
\hline Item & Control $(+)$ & $\begin{array}{c}\text { Control }(+) \text { with } \\
\text { Biostrong® } 510\end{array}$ & Control (-) & $\begin{array}{c}\text { Control (-) with } \\
\text { Biostrong® 510 }\end{array}$ \\
\hline Villi length $(\mu \mathrm{m})$ & & $534^{\mathrm{ab}}$ & $498^{\mathrm{b}}$ & $567^{\mathrm{a}}$ \\
& $467^{\mathrm{b}}$ & \pm 13.2 & \pm 27.45 & \pm 23.49 \\
Crypt Depth $(\mu \mathrm{m})$ & \pm 17.4 & $105^{\mathrm{b}}$ & $117^{\mathrm{b}}$ & $85^{\mathrm{c}}$ \\
& $127^{\mathrm{a}}$ & \pm 5.93 & \pm 6.62 & \pm 3.54 \\
Villi length to Crypt Depth Ratios & $3.7^{\mathrm{c}}$ & $5.08^{\mathrm{ab}}$ & $4.25^{\mathrm{b}}$ & $6.67^{\mathrm{a}}$ \\
& \pm 0.329 & \pm 0.356 & \pm 0.546 & \pm 0.301 \\
Small Intestine Thickness & $0.234^{\mathrm{a}}$ & $0.213^{\mathrm{ab}}$ & $0.221^{\mathrm{ab}}$ & $0.195^{\mathrm{b}}$ \\
(g Weight/cm Length) & \pm 0.008 & \pm 0.006 & \pm 0.007 & \pm 0.005 \\
\hline
\end{tabular}

Means \pm (Standard error)

Values within a row with different superscripts are significantly different $(P \leq 0.05)$.

$$
\text { Control (+) }
$$

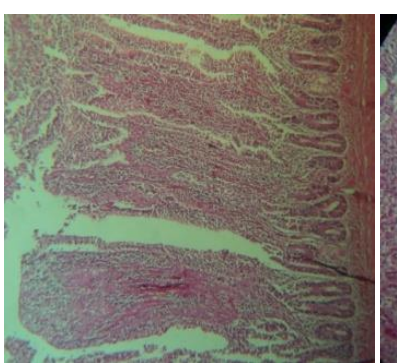

Control (+) with

Biostrong® 510

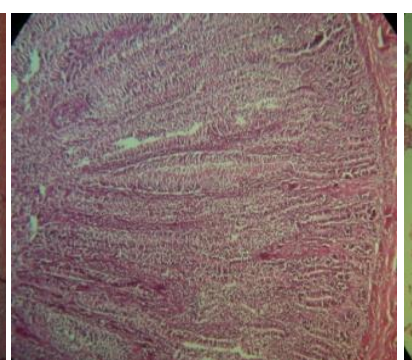

Control (-)

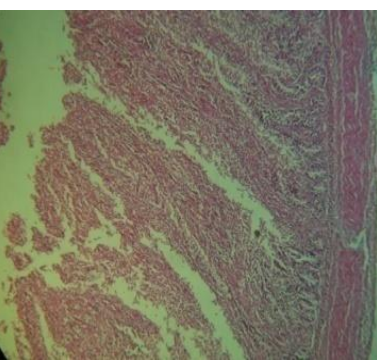

Control (-) with

Biostrong® 510

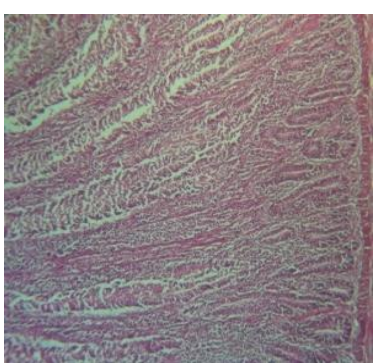

Fig. (1). Ileal villi height and crypt depth of chicks fed diets with or without PFA 


\section{CONCLUSION}

In conclusion, the main results indicate that addition of PFA (Biostrong ${ }^{\circledR} 510$ ) can improve the performance of broiler chicks at the later stage of growth. The beneficial mode of action of PFA may be related to its effect in increasing the count of Lactobacilli and reducing the number of E. coli and other pathogenic bacteria. It may also be related to the increase of the length of intestinal villi. Ultimately, PFA improved the performance of broiler chicks.

\section{REFERENCES}

Ahsan, U.; E. Kuter; I. Raza; B.H. Köksal; Ö. Cengiz; M. Yıldız; P.K. Kızanlık; M. Kaya; O. Tatlı and Ö. Sevim (2018). Dietary Supplementation of Different Levels of Phytogenic Feed Additive in Broiler Diets: The Dynamics of Growth Performance, Caecal Microbiota, and Intestinal Morphometry. Brazilian J. Poultry Sci. v.20 .737-746

Amad, A.A.; K. Manner; K.R. Wendler, K. Neumann and J. Zentek (2011) Effects of a phytogenic feed additive on growth performance and ileal nutrient digestibility in broiler chickens. Poultry Sci 90: 2811-2816

Amad, A.A.; K.R. Wendler and J. Zentek (2013). Effects of a phytogenic feed additive on growth performance selected blood criteria and jejuna morphology in broiler chickens. Emirate J Food Agri 25(7):549-554

Beiki M.; N. Dayyani and S. M. Hashemi (2013). The Effects of Fermacto, Bactocell and Biostrong® in Antibiotic-free Diets on the Performance of Broilers. Int J Adv Biol Biom Res. 1(11):1535-154

Cardoso, V. da S.; C. A. Lima; M. E. Lima; L. E. Dorneles and M. G. Danelli (2012). Piperine as a phytogenic additive in broiler diets. Pesq. agropec. bras. Brasília, v.47, n.4, p.489-496.

Cho, J.H.; H.J. Kim and I.H. Kim (2014) Effects of phytogenic feed additive on growth performance, digestibility, blood metabolites, intestinal microbiota, meat color and relative organ weight after oral challenge with Clostridium perfringens in broilers. Livest Sci 16:82-88

Duncan, D.B. (1955). Multiple range and Multiple F tests. Biometrics, 11: 1-42.

Doumas, B.; W. Watson and H. Biggs (1971). Albumin standard and measurements of serum albumin with bromocresol green. Clin. Chem. Act., 31: $87-88$.

El-Faham A.I.; Nematallah G.M. Ali and Hayam M.A.A. El-Maaty; (2014). Effect of Using Some Natural Feed Additives to Substitute Antibiotic Growth Promoters on Performance and Blood Parameters of Broilers. Egypt. Poult. Sci. Vol (34) (III): (735-750)

Hafeez A., K. Manner, C. Schieder and J. Zentek (2016). Effect of supplementation of phytogenic feed additives (powdered vs. encapsulated) on performance and nutrient digestibility in broiler chickens. Poultry Science; 95: 622-629.

Henery, R.J.A. (1964). Calorimetric method for the determination of the total protein. Clinical Chemical, Harper and Row Publisher, New York.

Kang, C.W.; L. Jungbauer; A. Mader and S. Jolain (2010). Effects of a phytogenic feed additive on Performance and bioavailability of nutrients in broilers. Proceedings XIIIth European Poultry Conference; Tours, France. 650

Knight, J., A. Andersonis and J.M. Rawal (1972). Chemical basis of the sula-phosphate vanillin reaction for estimating total serum lipid. Journal of Biology and Chemistry., 226-497.

Krinke, A.L. and D. Jamroz, (1996). Effect of feed antibiotic avoparcine on organ morphology in broiler chickens. Poultry Science 75: 705-710.

Leopold, J.; L. Alaban and R.W. Karola (2011). Effect of a phytogenic feed additive alone or in combination with a NSP enzyme on performance and nutrient digestibility in broilers. 18th European Symposium on Poultry Nutrition, 704- 706 


\section{Soliman}

Li, H.L.; P.Y. Zhao; Y. Lei; M. M. Hossain and I.H. Kim (2015). Phytoncide, phytogenic feed additive as an alternative to conventional antibiotics, improved growth performance and decreased excreta gas emission without adverse effect on meat quality in broiler chickens. Livestock Science 181, 1-6

Mohiti-Asli, M. and M. Ghanaatparast-Rashti (2017). Comparison of the effect of two phytogenic compounds on growth performance and immune response of broilers. J Appl Anim Res. 45:603-608

Mountzouris, K.C.; V. Paraskevas; P. Tsirtsikos; I. Palamidi; T. Steiner; G. Schatzmayr and K. Fegeros (2011). Assessment of a phytogenic feed additive effect on broiler growth performance, nutrient digestibility and caecal microflora composition. Anim Feed Sci Technol. 168:223-231.

Murugesan, G. R.; S. Basharat; Sudipto Haldar and P. Chasity (2015). Phytogenic feed additives as an alternative to antibiotic growth promoters in broiler chickens. Frontiers in Veterinary Science, Vol 2 , August

NRC (1994). Composition of Poultry Feed Stuffs. National Research Council. Nat Acad. Sci., Washington, D. C.

Paraskeuas, V.; K. Fegeros; I. Palamidi; C. Hunger and C. M. Konstantinos (2017). Growth performance, nutrient digestibility, antioxidant capacity, blood biochemical biomarkers and cytokines expression in broiler chickens fed different phytogenic levels. Animal Nutrition 3 114-120

SAS (1988). Institute, SAS user's Guide. SAS inst. Inc. Cary. N.C.

Saleh, A. A.; A. E. Tarek and A. M. Abudabos (2018). Effect of dietary phytogenics (herbal mixture) supplementation on growth performance, nutrient utilization, antioxidative properties, and immune response in broilers. Environ Sci Pollut Res 25:14606-14613

Saracila, M.; R.D. Criste; T.D. Panaite; P.A. Vlaicu; C. Tabuc; R.P. Turcu and M. Olteanu (2018). Artemisia Annua as Phytogenic Feed Additive in the Diet of Broilers (14-35 Days) Reared under Heat Stress $\left(32^{\circ} \mathrm{C}\right)$. Brazilian J. Poultry Sci. v.20, No. 4, 825-832

Scheuermann, G.N.; A. Cunha Junior; L. Cypriano and A.M. Gabbi (2009). Phytogenic additive as an alternative to growth promoters in broiler chickens. Ciência Rural, v.39, p.522-527,

Stutz, M. W.; S.L. Johnson and F.R. Judith (1983). Effect of diet bacitracin and body weight restriction on the intestine of broiler chicks. Poultry Science 62: 1626- 1632.

Ultee, A.; M.H.J. Bennik; and R. Moezelaar (2002). The phenolic hydroxyl group of carvacrol is essential for action against the food-borne pathogen Bacillus cereus. Appl Environ Microb. 68:1561-1568

Wati, T.; T.K. Ghosh; B. Syed and S. Haldar (2015). Comparative efficacy of a phytogenic feed additive and an antibiotic growth promoter on production performance, caecal microbial population and humoral immune response of broiler chickens inoculated with enteric pathogens. Animal Nutrition $2015 ; 1: 213-219$.

Watson, D. (1960). A simple method for the determination of serum cholesterol. Clinical Chemistry., 5: 637.

كفاءة منشطات النمو النباتية فى تحسين الأداء الأنتاجى وبكتريا ونسيج الأمعاء لكتاكيت اللحم

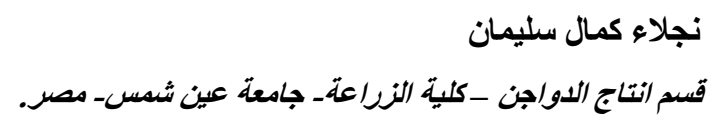

منشطات النمو الطبيعة نباتية المصدر تم اختبارها فى عديد من الأبحاث كمنشط للنمو بديل عن المضادات الحيوية التى تم تحريم

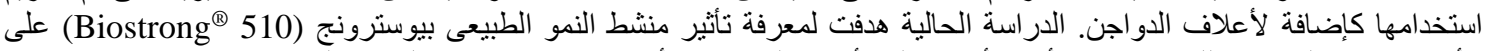

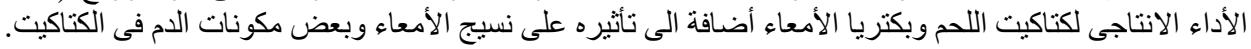

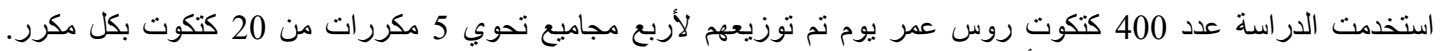

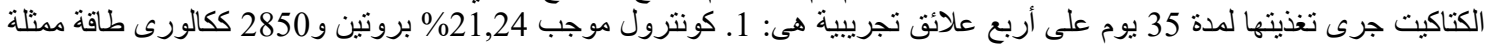

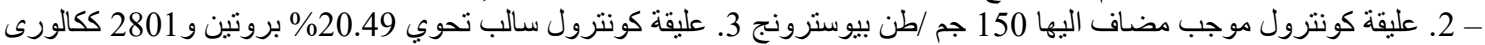
طاقة ممثلة 4. عليقة كونترول سالب مضاف اليها 150 جم /طن بيوسترونج. 
أضافة البيوسترونج لعلائق كتاكيت اللحم أدى لزيادة وزن الجسم وتحسين معدل التحويل الغذائى للكتاكيت مقارنة بتلك المغذاة على الإي

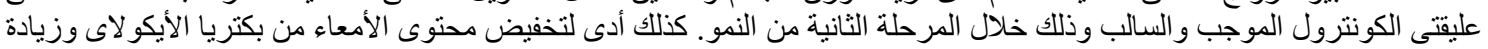

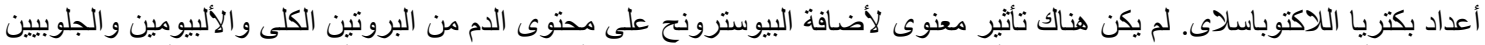

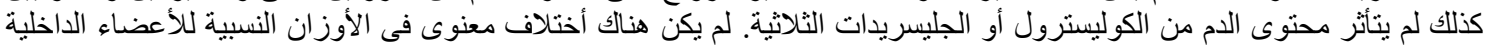

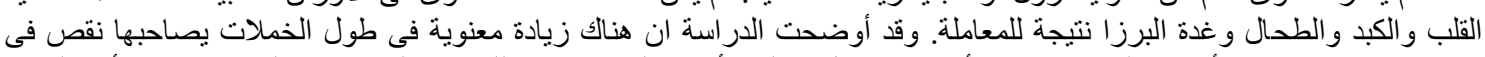
Crypt depth

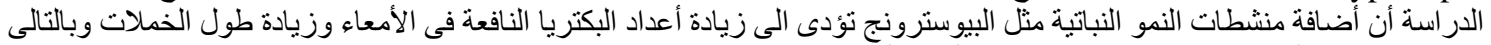

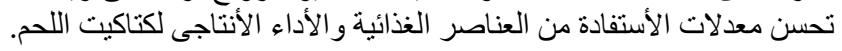

